\title{
Guidelines for the Primary Care of Lesbian, Gay, and Bisexual People: A Systematic Review
}

Ruth P. McNair, MBBS, DRANZCOG, DA(UK), FRACGP, PbD

Kelsey Hegarty, MBBS, FRACGP, $\mathrm{PbD}$

Department of General Practice, University of Melbourne, Australia

Conflicts of interest: none reported

\section{CORRESPONDING AUTHOR}

Ruth P. McNair, MBBS, DRANZCOG $\mathrm{DA}(\mathrm{UK})$, FRACGP, PhD

Department of General Practice

University of Melbourne

200 Berkeley St

Carlton, Victoria 3053

Australia

r.mcnair@unimelb.edu.au

\begin{abstract}
PURPOSE We assessed whether existing guidelines for the primary care of lesbian, gay, and bisexual (LGB) people meet appropriate standards of developmental rigor, and whether they provide consistent recommendations useful for primary care clinicians.

METHODS We performed a systematic review of such guidelines using the Cochrane Collaboration method. The countries searched were Australia, Canada, Ireland, New Zealand, the United Kingdom, and the United States. For sources, we used electronic databases, guidelines databases, primary care professional organizations, government departments of public health, LGB health care textbooks, and national LGB organizations. We assessed the quality of existing guidelines using the validated Appraisal of Guidelines for Research and Evaluation (AGREE) instrument and compared the recommendations from all fully appraised guidelines.
\end{abstract}

RESULTS Our search did not identify any previous systematic reviews on primary care of LGB people. Of 2,421 documents identified, we initially reviewed 30 and fully appraised 11, none of which completely satisfied the AGREE criteria for quality and only 2 of which were specifically designed for primary care. Developmental rigor was poor. Particular gaps were a lack of explicit inclusion criteria, independent reviewers, and updating procedures. Nonetheless, we did identify several consistent recommendations pertinent to primary care settings: guidance on inclusive clinical environments, standards for clinician-patient communication, sensitive documentation of sexual orientation, knowledge for cultural awareness, staff training, and addressing population health issues.

CONCLUSIONS Currently available guidelines for LGB care are philosophically and practically consistent, and provide a degree of evidence-based clinical and systems support to primary care clinicians. There is a need, however, for evidencebased LGB guidelines that are more rigorously developed, disseminated, and evaluated specifically for the primary care setting.

Ann Fam Med 2010;8:533-541. doi:10.1370/afm.1173.

\section{INTRODUCTION}

he primary care of lesbian, gay, and bisexual (LGB) people is compromised by gaps in clinical care and practice systems. ${ }^{1}$ These gaps include documented deficiencies in the LGB-specific knowledge and skills of health care professionals, ${ }^{1}$ which are, in part, explained by a lack of training about LGB health at all levels of their education. ${ }^{2,3}$ Clinician knowledge is also limited by the dearth of available population-based data, ${ }^{4}$ although such studies are increasingly being conducted. ${ }^{5}$ Further, the practice environment is affected by the contentious and stigmatized nature of homosexuality, with health care professionals holding a range of beliefs about minority sexual orientation that are occasionally pathologizing and commonly minimizing. ${ }^{6}$ Clinician beliefs that sexual orientation is irrel- 
evant form a major barrier to patient disclosure within consultations, ${ }^{7}$ and few primary care services create a practice environment that demonstrates awareness of and respect for LGB patients as a group. ${ }^{8}$ This lack of awareness and respect has been described as a "blind spot" among family physicians toward LGB patients, ${ }^{9}$ and it leads to reports by LGB people of difficulty in accessing culturally competent primary care services. ${ }^{10}$

LGB-specific services have been developed to overcome these deficiencies ${ }^{11}$; however, there is a pressing need for mainstream services to become culturally competent in this area. ${ }^{12,13}$ We assert that such cultural competence should be LGB-specific rather than generic to overcome a tendency to disregard minority sexual orientation in clinical care. Many family physicians prefer to avoid stereotyping and remain neutral by ignoring numerous specific cultural attributes; as a result, crucial differences that influence health are missed. ${ }^{14}$

Clinical practice guidelines for LGB health care would assist in improving clinicians' knowledge and skills ${ }^{15}$; however, few guidelines are available, creating a further barrier to effective practice. ${ }^{2}$ Policies on lesbian and gay health do exist within some medical associations ${ }_{1}^{16,17}$ although the associations have been slow to translate these policies into standards of practice and education. ${ }^{18}$ Health policy at the government level also often lacks LGB-specific focus, which further discourages LGB sensitivity among educators or clinicians. ${ }^{19}$ To be most effective, guidelines must be accompanied by a range of other educational methods including audits, training, and feedback ${ }^{20}$; nevertheless, they can serve to raise the awareness of clinicians to the LGB population group. Guidelines that provide easy access to current evidence in the area and clear recommendations on day-to-day care are more likely to be put into practice by clinicians. ${ }^{21,22}$

We undertook a systematic review to determine whether existing LGB guidelines for primary care meet appropriate standards of rigor in their development and to summarize areas of consistency that provide practical guidance for primary care clinicians.

\section{METHODS}

Our review process was based on that outlined in the Cocbrane Handbook for Systematic Reviews of Interventions. ${ }^{23}$

\section{Search Strategy}

We limited our search to 6 source countries-Australia, Canada, Ireland, New Zealand, the United Kingdom, and the United States - as these are the major English-speaking countries with primary care systems that have some similarity. We used multiple data sources and search terms as shown in Table 1 . The search terms were designed to systematically identify documents with a focus on LGB people in primary care settings. We did not focus on transgender or intersex individuals, although some of the documents included these populations. After finding few relevant guidelines through the peer-reviewed data sources, we next searched Web sites of general practice and nursing primary care organizations in each country, and health department Web sites. We also identified relevant textbooks published since 1995 through Google Book.

\section{Inclusion Criteria for the Initial Review}

We used the validated Appraisal of Guidelines for Research and Evaluation (AGREE) instrument, which has been designed to assess guidelines for the quality of reporting, the quality of the recommendations, and the likelihood that they will achieve the intended outcome. ${ }^{24}$ The instrument has been increasingly used by guideline developers and collators, including the Guidelines International Network. ${ }^{25}$ It contains 23 items in 6 domains, and inclusion criteria for our initial review related to 4 of these domains: Scope and Purpose, Stakeholder Involvement, Rigor of Development, and Clarity and Presentation. Our specific inclusion criteria were an explicit LGB and primary care scope and purpose; at least some involvement of stakeholders, including health care professionals, researchers, and LGB consumers; developmental rigor that demonstrated explicit links between research evidence about LGB health and the recommendations; and clear presentation pertaining to the practice environment and specific knowledge for LGB cultural awareness. We did not regard the final 2 AGREE domains of Applicability and Editorial Independence as inclusion criteria for initial review as they were very rarely addressed.

\section{Selection Process for Full Appraisal}

One of the authors (R.P.M.) reviewed all abstracts of the papers found on the initial search and excluded those that did not satisfy the LGB and primary care scope. Both authors then independently read the full documents identified for an initial review and excluded those that did not meet our inclusion criteria in the 4 AGREE domains. Several documents were excluded on the basis of poor methodology, inadequate or nonexistent involvement of stakeholders, limited or no specific recommendations, or some combination thereof.

Both authors fully appraised the remaining documents independently, which followed the AGREE recommendation that each of the reviewed guidelines be assessed independently by at least 2 reviewers. Each reviewer independently rated the document on the items in the 6 domains using a 4 -point scale: 4 = strongly agree, 3 = agree, 2 = disagree, $1=$ strongly 


\section{Table 1. Search Results}

\begin{tabular}{|c|c|c|c|}
\hline Initial Search Source & $\begin{array}{l}\text { Initial } \\
\text { Result }\end{array}$ & $\begin{array}{l}\text { Satisfied } \\
\text { Inclusion } \\
\text { Criteria }\end{array}$ & $\begin{array}{l}\text { Selected } \\
\text { for Full } \\
\text { Appraisal }\end{array}$ \\
\hline \multicolumn{4}{|l|}{ Electronic databases $^{\mathrm{a}}$} \\
\hline Lesbian, gay AND primary care NOT HIV,STI & 598 & & \\
\hline Lesbian, gay AND physician, family NOT HIV,STI & 436 & & \\
\hline Guideline\$ AND lesbian AND physician, family & 129 & & \\
\hline Guideline \$ AND bisexual women AND physician, family & 78 & & \\
\hline Guideline $\$$ AND lesbian AND primary care & 164 & & \\
\hline Guideline $\$$ AND bisexual women AND primary care & 101 & & \\
\hline Recommend\$ AND lesbian health & 63 & & \\
\hline Recommend\$ AND lesbian AND physician, family & 31 & & \\
\hline $\begin{array}{l}\text { Recommend } \$ \text { AND bisexual women AND physician, } \\
\text { family }\end{array}$ & 19 & & \\
\hline Recommend\$ AND lesbian AND primary care & 45 & & \\
\hline Recommend $\$$ and bisexual women AND primary care & 30 & & \\
\hline Polic\$ AND lesbian health & 34 & & \\
\hline Guideline $\$$ and male homosexual AND physician, family & 103 & & \\
\hline Guideline $\$$ and bisexual men AND physician, family & 104 & & \\
\hline Guideline $\$$ and male homosexual AND primary care & 124 & & \\
\hline Guideline $\$$ and bisexual men AND primary care & 126 & & \\
\hline $\begin{array}{l}\text { Recommend\$ AND male homosexual AND physician, } \\
\text { family }\end{array}$ & 50 & & \\
\hline Recommend $\$$ AND bisexual men AND physician, family & 29 & & \\
\hline Recommend\$ AND male homosexual AND primary care & 63 & & \\
\hline Recommend $\$$ and bisexual men AND primary care & 36 & & \\
\hline Polic $\$$ AND gay men's health & 17 & 10 & 0 \\
\hline \multicolumn{4}{|l|}{ Cochrane Collaboration } \\
\hline Database of Systematic Reviews & 0 & & \\
\hline Central Register for Clinical Trials & 2 & 0 & 0 \\
\hline \multicolumn{4}{|l|}{ Guidelines databases } \\
\hline $\begin{array}{l}\text { NHMRC (Australia), Guidelines International Network } \\
\text { (Europe), NICE (UK), Canadian Medical Association Clini- } \\
\text { cal Practice Guidelines, New Zealand Guidelines Group }\end{array}$ & 0 & & \\
\hline US National Guidelines Clearinghouse & 13 & 0 & 0 \\
\hline \multicolumn{4}{|l|}{ Primary care and public health organizations } \\
\hline $\begin{array}{l}\text { RACGP (Australia), RNZCGP (New Zealand), RCGP (UK), } \\
\text { ICGP (Ireland), College of Family Physicians (Canada), } \\
\text { American Academy of Family Physicians (US) }\end{array}$ & 0 & & \\
\hline UK Royal College of Nursing & 1 & 1 & 1 \\
\hline \multicolumn{4}{|l|}{ Government Departments of Health } \\
\hline $\begin{array}{l}\text { Massachusetts, Washington, Quebec, British Columbia, } \\
\text { Ontario, Kaiser Permanente (US), Department of } \\
\text { Health (UK), NHS Scotland }\end{array}$ & 8 & 8 & 5 \\
\hline LGBT-specific textbooks & 12 & 6 & 2 \\
\hline \multicolumn{4}{|l|}{ LGB organization Web sites } \\
\hline $\begin{array}{l}\text { Stonewall (UK), US National Coalition for LGBT Health, } \\
\text { Mautner National Lesbian Health Project (US) }\end{array}$ & 0 & & \\
\hline $\begin{array}{l}\text { Gay and Lesbian Health Victoria, Gay and Lesbian } \\
\text { Medical Association (US), International Lesbian and } \\
\text { Gay Association, PACE (UK), Gay and Lesbian Equality } \\
\text { Network (Ireland) }\end{array}$ & 5 & 5 & 3 \\
\hline Total & 2,421 & 30 & 11 \\
\hline \multicolumn{4}{|c|}{$\begin{array}{l}\text { ICGP = Irish College of General Practitioners; LGB = lesbian, gay, and bisexual; LGBT = lesbian, gay, bisexual, and } \\
\text { transgender; NHMRC = National Health and Medical Research Council; NICE = National Institute for Health and } \\
\text { Clinical Excellence; PACE = Project for Advice, Counselling and Education; RACGP = Royal Australian College of Gen- } \\
\text { eral Practitioners; RCGP = Royal College of General Practitioners; RNZCGP = Royal New Zealand College of General } \\
\text { Practitioners; STI = sexually transmitted infection. }\end{array}$} \\
\hline \multicolumn{4}{|c|}{$\begin{array}{l}\text { Notes: Values are numbers of documents. The } \$ \text { symbol is a truncation symbol enabling the search engine to find } \\
\text { word variations on that stem or alternate spellings. }\end{array}$} \\
\hline $\begin{array}{l}\text { a MEDLINE, Web of Science, CINAHL Plus, PsycINFO, PubMed, Acader } \\
\text { restriction used. }\end{array}$ & ic Search P & emier (EBSCO ho & t); no date \\
\hline
\end{tabular}

disagree. We then calculated a score for each domain, and met to compare scores and calculate the standardized score of each domain for each document. The formulas for calculating the scores for each domain are as follows: the maximum possible score was $4 \times$ the number of items $\times$ the number of appraisers; the minimum possible score was $1 \times$ the number of items $X$ the number of appraisers. Using these values, the standardised domain score expressed as a percentage is the obtained score minus the minimum possible score, divided by the maximum possible score minus the minimum possible score. Hence, the final domain score was the mean percentage score of the 2 reviewers according to the AGREE scoring system, with possible scores ranging from $0 \%$ to $100 \% .{ }^{24}$ The higher the percentage, the higher the quality of the guideline for that AGREE domain.

Finally, we considered whether a distribution plan was in place, as there is evidence that guidelines are more influential if they have been endorsed by professional bodies and undergone widespread distribution and piloting. ${ }^{15,22}$

\section{RESULTS}

\section{Review Outcome}

We identified 2,421 publications on the initial search, 30 of which fulfilled our minimum criteria for initial review, and 11 of which satisfied our inclusion criteria for full appraisal (Table 1). Five sources generated the 11 documents. One document was from a primary care organization, the Royal College of Nursing in the 


\section{Table 2. Documents Included in the Full Appraisal}

\begin{tabular}{|c|c|c|c|c|}
\hline Country & Document No., Title, and Authors & $\begin{array}{l}\text { Funderl } \\
\text { Publisher }\end{array}$ & Target & Type and Length \\
\hline United States ${ }^{11,27}$ & $\begin{array}{l}\text { 1. Community Standards of Practice for Provision } \\
\text { of Quality Health Care Services for Gay, Lesbian, } \\
\text { Bisexual and Transgendered Clients; GLBT Health } \\
\text { Access Project }\end{array}$ & $\begin{array}{l}\text { Massachusetts } \\
\text { Department of } \\
\text { Public Health }\end{array}$ & $\begin{array}{l}\text { Public health care } \\
\text { services }\end{array}$ & Booklet, 7 pages \\
\hline United States ${ }^{31}$ & $\begin{array}{l}\text { 2. A Provider's Handbook on Culturally Competent } \\
\text { Care: Lesbian, Gay, Bisexual and Transgendered } \\
\text { Population; Kaiser Permanente National Diver- } \\
\text { sity Council }\end{array}$ & Kaiser Permanente & $\begin{array}{l}\text { Kaiser Permanente } \\
\text { clinicians }\end{array}$ & Booklet, 71 pages \\
\hline United States ${ }^{36}$ & $\begin{array}{l}\text { 3. Guidelines for Care of Lesbian, Gay, Bisexual and } \\
\text { Transgender Patients; GLMA }\end{array}$ & $\begin{array}{l}\text { GLMA; sponsored } \\
\text { by Pfizer US }\end{array}$ & Clinicians & $\begin{array}{l}\text { Booklet, } 45 \text { pages }+ \\
\text { online }\end{array}$ \\
\hline Canada $^{2}$ & $\begin{array}{l}\text { 4. Caring for Lesbian and Gay People: A Clinical } \\
\text { Guide; Peterkin and Risdon }\end{array}$ & None disclosed & Clinicians & $\begin{array}{l}\text { Textbook, } 378 \text { pages } \\
+ \text { online }\end{array}$ \\
\hline Australia $33-35$ & $\begin{array}{l}\text { 5. Health and Sexual Diversity. A Health and Well- } \\
\text { being Action Plan for Gay, Lesbian, Bisexual, Trans- } \\
\text { gender and Intersex (GLBTI) Victorians; Leonard }\end{array}$ & $\begin{array}{l}\text { Department of } \\
\text { Human Services, } \\
\text { Victoria }\end{array}$ & $\begin{array}{l}\text { Health care } \\
\text { services }\end{array}$ & $\begin{array}{l}\text { Reports, } 136 \text { pages, } \\
\text { and booklet, } 4 \\
\text { pages + online }\end{array}$ \\
\hline United Kingdom ${ }^{26}$ & $\begin{array}{l}\text { 6. Not 'Just' A Friend: Best Practice Guidance on } \\
\text { Health Care for Lesbian, Gay and Bisexual Service } \\
\text { Users and Their Families; Royal College of Nurs- } \\
\text { ing and UNISON }\end{array}$ & $\begin{array}{l}\text { Royal College } \\
\text { of Nursing \& } \\
\text { UNISON }^{\mathrm{a}}\end{array}$ & $\begin{array}{l}\text { NHS health } \\
\text { workers }\end{array}$ & Booklet, 12 pages \\
\hline United States ${ }^{28}$ & $\begin{array}{l}\text { 7. Culturally Competent Care for GLBT People: Rec- } \\
\text { ommendations for Health Care Providers; Public } \\
\text { Health, Seattle and King County }\end{array}$ & NNLM grant & Clinicians & $\begin{array}{l}\text { Web site, } 10 \text { Web } \\
\text { pages }\end{array}$ \\
\hline United Kingdom ${ }^{29}$ & $\begin{array}{l}\text { 8. Fair for All-The Wider Challenge. Good LGBT } \\
\text { Practice in the NHS; NHS Inclusion Project and } \\
\text { Stonewall Scotland }\end{array}$ & $\begin{array}{l}\text { NHS Scotland and } \\
\text { Stonewall Scotland }\end{array}$ & $\begin{array}{l}\text { Staff in all areas of } \\
\text { NHS }\end{array}$ & Report, 51 pages \\
\hline United States ${ }^{32}$ & $\begin{array}{l}\text { 9. Fenway Guide to Lesbian, Gay, Bisexual and } \\
\text { Transgender Health; Makadon et al }\end{array}$ & $\begin{array}{l}\text { American College of } \\
\text { Physicians }\end{array}$ & $\begin{array}{l}\text { Primary care } \\
\text { clinicians }\end{array}$ & Textbook, 526 pages \\
\hline Canada ${ }^{30}$ & $\begin{array}{l}\text { 10. Caring for Lesbian Health: A Resource for Cana- } \\
\text { dian Health Care Providers, Policy Makers and } \\
\text { Planners; Hudspith }\end{array}$ & Health Canada & $\begin{array}{l}\text { Canadian clini- } \\
\text { cians, policy } \\
\text { makers, planners }\end{array}$ & Report, 37 pages \\
\hline Ireland ${ }^{37}$ & $\begin{array}{l}\text { 11. Lesbian, Gay \& Bisexual Patients: The Issues for } \\
\text { General Practice; Allen }\end{array}$ & $\begin{array}{l}\text { Irish College of Gen- } \\
\text { eral Practitioners }\end{array}$ & $\begin{array}{l}\text { Irish general } \\
\text { practitioners }\end{array}$ & Report, 24 pages \\
\hline
\end{tabular}

United Kingdom. ${ }^{26}$ Four documents were from government departments of health in Massachusetts, ${ }_{1}{ }^{27}$ Washington State, ${ }^{28}$ Scotland, ${ }^{29}$ and British Columbia. ${ }^{30}$ A US private health care agency, Kaiser Permanente, had also produced a clinician's handbook on LGB and transgender culturally competent care. ${ }^{31}$ Two textbooks fulfilled the criteria for full appraisal, ${ }^{2,32}$ as did 3 sets of documents from leading LGB organizations in Australia, ${ }^{33-35}$ the United States, ${ }^{36}$ and Ireland. ${ }^{37} \mathrm{We}$ have summarized the characteristics of the 11 fully appraised documents in Table 2 .

\section{Guideline Quality According to Appraisal Scores}

We obtained a high level of agreement on our independent AGREE domain scores for each fully appraised document, with all but 2 scores being within 2 points. We then calculated the combined standardized AGREE scores as a percentage for each document, as recommended by the AGREE developers (Table 3). None of the selected guidelines fully satisfied the AGREE criteria in all domains. The highest standards were achieved for the Scope and Purpose domain (indicat- ing that guidelines were about LGB people and could apply to primary care), which was expected as this was our primary inclusion criterion for initial review. Only 1 textbook $^{32}$ and the Irish document ${ }^{37}$ were specifically designed for primary care.

Scores for the Stakeholder Involvement domain varied widely. Most documents scored well on clearly defining the target users. Individuals from relevant professional groups who were involved in the development were usually just a small range of expert clinicians, researchers, or both. Just 3 documents sought patients' views and preferences. ${ }^{27,29,34}$ The best examples in this domain were the Justice Resource Institute engagement of a multidisciplinary working group of more than 60 people, including consumers, ${ }^{27}$ and a wide-ranging consultation process with consumers in Scotland. ${ }^{29}$ Only 1 group ${ }^{29}$ pilot tested its guide among target users.

The clarity of presentation quality also varied and was best in the 2 textbooks, ${ }^{2,32}$ with their large format; extensive resource lists, tables, and examples of forms; and inclusion of useful summaries at the end of each chapter. Three of the documents ${ }^{2,28,35}$ were accom- 
panied by extensive resources on a linked Web site, which added to their presentation quality and availability. The final domains of Applicability and Editorial Independence were poorly addressed in all of the documents. Low applicability, in particular, creates a practical problem in cases where services and clinicians might want to use the guidelines, but the guidelines do not list barriers, costs, or review criteria.

All of the fully appraised documents scored poorly in the Rigor of Development domain as well. We describe the documents' performance on each of the 7 items in this domain below, as we consider the evidence base of guidelines to be crucial to their value in the clinical setting given the difficulty clinicians have in accessing evidence regarding LGB health.

- First, none of the guidelines documented use of systematic methods for their literature review. As a result, guidelines could be subject to bias or reflect a particular assumption of the authors. For example, the Irish guidelines contained a statement that "being lesbian, gay or bisexual is not a preference and is not chosen. It is integral to a person's...identity rather than being a lifestyle." ${ }^{1 /(\mathrm{p} 5)}$ This statement reflects just 1 essentialist perspective without offering an alternative social constructivist perspective that has equal validity in the literature. ${ }^{38}$ Further, there was a tendency for North American documents to restrict their literature reviews to local studies and exclude relevant international work.

- Second, the Rigor domain requires that the inclusion and exclusion criteria for selecting evidence be described, which was not done in any docu- ment. Two documents referred to levels of evidence and occasionally described them, but did not have explicit criteria. ${ }^{34,37}$

- Third, a description of how the recommendations were formulated was included in only 4 documents, and these descriptions were not detailed. ${ }^{27,29,32,34}$ The methods used were expert opinion, ${ }^{32}$ consensus following empirical evidence from interviews or focus groups, ${ }^{27}$ or consensus following stakeholder consultation. ${ }^{29,33}$

- Fourth, all but 3 documents mentioned the benefits of their recommendations; however, none considered risks or alternative possibilities.

- Fifth, the recommendations should be explicitly linked with the evidence. Scores within the domain were highest for this item, as 5 documents provided excellent or very good links. 2, 27,31,32,37 But 4 documents did not provide any links at all.

- Sixth, the guidelines should be reviewed by an independent expert before publication, but none of the documents stated that such review had been done.

- Finally, the guidelines should include a procedure for updating, including a time line, and just 1 document complied in this regard. ${ }^{29}$

In addition to assessing the AGREE criteria, we assessed whether the documents contained any process for dissemination to or engagement of primary care clinicians. Three of the documents had a dissemination strategy. Kaiser Permanente distributed its standards to all of its own health care professionals as well as to all medical schools in the United States. ${ }^{39}$ The UK Royal

\section{Table 3. Standardized AGREE Domain Scores for the Appraised Documents}

\begin{tabular}{|c|c|c|c|c|c|c|}
\hline \multirow[b]{2}{*}{$\begin{array}{l}\text { Document } \\
\text { No. }{ }^{a}\end{array}$} & \multicolumn{6}{|c|}{ Domain } \\
\hline & $\begin{array}{l}\text { Scope and } \\
\text { Purpose }\end{array}$ & $\begin{array}{l}\text { Stakeholder } \\
\text { Involvement }\end{array}$ & $\begin{array}{c}\text { Rigor of } \\
\text { Development }\end{array}$ & $\begin{array}{l}\text { Clarity and } \\
\text { Presentation }\end{array}$ & Applicability & $\begin{array}{c}\text { Editorial } \\
\text { Independence }\end{array}$ \\
\hline 9 & 100 & 42 & 29 & 100 & 11 & 17 \\
\hline 11 & 100 & 54 & 33 & 83 & 6 & 42 \\
\hline 1 & 94 & 83 & 21 & 75 & 61 & 42 \\
\hline 4 & 89 & 21 & 21 & 83 & 22 & 8 \\
\hline 6 & 89 & 17 & 5 & 71 & 6 & 17 \\
\hline 2 & 89 & 38 & 24 & 46 & 0 & 0 \\
\hline 5 & 83 & 67 & 12 & 58 & 22 & 33 \\
\hline 3 & 78 & 21 & 5 & 79 & 11 & 0 \\
\hline 7 & 78 & 8 & 0 & 75 & 0 & 42 \\
\hline 8 & 72 & 92 & 29 & 42 & 44 & 0 \\
\hline 10 & 50 & 42 & 0 & 71 & 28 & 25 \\
\hline \multicolumn{7}{|c|}{ AGREE = Appraisal of Guidelines for Research and Evaluation. } \\
\hline \multicolumn{7}{|c|}{ a See Table 2 for details on each document. } \\
\hline \multicolumn{7}{|c|}{$\begin{array}{l}\text { Notes: Domain scores are mean percentage score of the } 2 \text { reviewers calculated according to the AGREE scoring system, wherein possible scores range from } 0 \% \text { to } \\
100 \% .{ }^{24} \text { The higher the percentage, the higher the quality of the guideline for that AGREE domain. }\end{array}$} \\
\hline
\end{tabular}


College of Nursing standards gained endorsement from 4 allied health colleges, and from the sponsoring union (UNISON), which assisted in distribution. ${ }^{26}$ The Irish document ${ }^{37}$ had the most comprehensive process. This document was launched at the Irish College of General Practitioners' annual conference and then sent to every general practitioner in Ireland by the College (e-mail communication, Odhrán Allen; March 9, 2010). Moreover, some of the guidelines have been incorporated into the Irish general practitioner training curriculum.

\section{Synthesis of Recommendations}

We compared the recommendations within the 11 fully appraised documents and conducted a thematic and content analysis. All documents used common principles of cultural competency, equity, or the need for awareness of LGB patients and their diversity. We also found considerable concordance among the documents on many of the individual recommendations. The majority of documents contained recommendations that related to both practice systems and clinical care. We noted several consistent themes regarding practice systems: inclusive clinical environments; documentation; staff and training; and population health. Themes pertaining to clinical care were areas of LGB-specific knowledge, and clinician-patient communication. These common themes and recommendations are shown in Table 4.

An important weakness was the limited or lacking guidance provided for clinicians on disclosure of sexual orientation, which has been found to be a considerable challenge for patients and clinicians alike. ${ }^{7}$ Very few documents focused on how to facilitate disclosure, and only 3 discussed the need to respect the patient's choice not to disclose (Table 4). ${ }^{28,31,36}$ In addition, few included recommendations on documentation issues, and none mentioned LGB sensitivity in referral letters. Only 4 documents recommended forming a partnership with LGB agencies, despite the importance of such partnership for the provision of resources and for referral to LGB community services. ${ }^{27,29,30,34}$ Finally, a population health focus was unusual, and in particular, only 3 documents noted the need for clinicians to advocate on behalf of LGB patients. ${ }^{27,31,32}$

\section{DISCUSSION}

This is the first systematic review of LGB guidelines that we are aware of. Our review was strengthened by the broad range of data sources accessed, including government and LGB organization Web sites, which turned out to be the sources of the majority of the fully appraised documents. A further strength was the use of the validated AGREE instrument to appraise documents and so provide an indication of their quality. In addition, the rigor of the review process was enhanced by having 2 reviewers conducting independent appraisal. Although the broad range of data sources was a strength, it arose from a limitation. Our initial search of databases revealed a complete absence of LGB-focused guidelines, which necessitated a search of individual organizations and government departments. This lack of guidelines in commonly used databases highlights the difficulty that health care professionals and organizations are likely to have in finding relevant guidelines. It also led to a limitation of this review in that inevitably, we were unable to find all relevant guidelines because we could not search every government department or LGB agency in the countries of interest.

We synthesized the recommendations into a cohesive and, we suggest, clinically useful set of guidelines for the primary care of LGB people. Such guidelines have the capacity to be "a potential change agent in the health care system ${ }^{\prime 20(p 6)}$ by enabling clinicians and managers to translate current research evidence into clinical practice. ${ }^{20}$ Conversely, guidelines that contradict existing values of clinicians, or highlight new knowledge and skills that are needed can "demand too much change to existing routines" $22(\mathrm{p} 860)$ and therefore reduce the likelihood of guidelines uptake by clinicians. ${ }^{22}$

We suggest that LGB guidelines development should be improved in the following ways to ensure reliability and uptake. Involvement of LGB stakeholders in consultation would assist in addressing diversity within LGB groups as well as ensuring that issues of clinical environment, confidentiality, and communication are truly patient centered. Rigor would be improved by the use of a systematic review, which would ensure inclusion of international LGB research and address multiple theoretical perspectives. Another essential element in presentation of the recommendations is to reference all recommendations with the evidence on which they are based.

A further method to improve the rigor of guideline development is to detail the inclusion and exclusion criteria for the review, particularly as minority sexual orientation is such a multidimensional phenomenon. For example, guidelines should state whether transgendered gay and lesbian people, or bisexual women, or heterosexually identified men who have sex with men are included as a target group. External review by an independent expert would also improve the perceived reliability of the guideline. We suggest that the most effective reviewers for primary care LGB guidelines would be mainstream researchers or practitioners in the primary care field. The Irish guide came closest to this model in that a gay and lesbian organization 


\section{Table 4. Recommendations Collated From the Appraised Documents}

\begin{tabular}{|c|c|c|c|}
\hline Recommendation & Document No. ${ }^{a}$ & Recommendation & Document No. ${ }^{a}$ \\
\hline Principles & & Documentation & \\
\hline Cultural competency/social model of health & & Medical notes & \\
\hline $\begin{array}{l}\text { Person-centered, LGB as a cultural and } \\
\text { lifestyle issue }\end{array}$ & $\begin{array}{l}1,2,3,4,6,7 \\
9,10\end{array}$ & $\begin{array}{l}\text { Permission to document sexual orientation } \\
\text { Inform patient what is written }\end{array}$ & $\begin{array}{l}4,6,7 \\
3\end{array}$ \\
\hline Equity and human rights & & Referral letters & - \\
\hline $\begin{array}{l}\text { Importance of antidiscrimination policy } \\
\text { including sexual orientation }\end{array}$ & $\begin{array}{l}1,2,3,5,6,7,8 \\
9,10,11\end{array}$ & Decision makers/next of kin & \\
\hline Awareness of the LGB population & & $\begin{array}{l}\text { Ask and document emergency contact, } \\
\text { who makes decisions }\end{array}$ & 6,9 \\
\hline $\begin{array}{l}\text { Understanding the proportion of LGB } \\
\text { patients and removing assumptions of } \\
\text { heterosexuality }\end{array}$ & $\begin{array}{l}1,2,3,4,6,7,8 \\
9,10,11\end{array}$ & $\begin{array}{l}\text { Special knowledge for cultural awareness } \\
\text { Impact of discrimination on health }\end{array}$ & \\
\hline $\begin{array}{l}\text { Aware of multiple minority status: SES, } \\
\text { disability, race }\end{array}$ & $2,3,4,8,9,10$ & Experiences of violence and harassment & $\begin{array}{l}2,3,4,5,8,9 \\
10,11\end{array}$ \\
\hline Inclusive of LGB families & $\begin{array}{l}1,2,4,5,6,7,8 \\
9,10,11\end{array}$ & $\begin{array}{l}\text { Reduced level of support from family and } \\
\text { community }\end{array}$ & 9 \\
\hline Inclusive clinical environment & & Mental health & \\
\hline Overt signs/displays & & Higher rates of depression, anxiety, & $2,3,4,5,7,9$ \\
\hline $\begin{array}{l}\text { Rainbow sticker, posters, brochures, } \\
\text { information }\end{array}$ & $\begin{array}{l}3,4,5,7,8,9 \\
10,11\end{array}$ & $\begin{array}{l}\text { suicidalıty } \\
\text { Drugs, alcohol, smoking }\end{array}$ & \\
\hline LGB magazines, newspapers & $3,8,9$ & $\begin{array}{l}\text { Higher rates of use over a longer period } \\
\text { of time }\end{array}$ & $\begin{array}{l}2,3,4,5,7,9 \\
10,11\end{array}$ \\
\hline Seceptionists and other staff & $1,4,5,8,9$ & $\begin{array}{l}\text { Fertility, pregnancy, parenting } \\
\text { Sexual health, safer sex }\end{array}$ & $2,4,5,9,10$ \\
\hline $\begin{array}{l}\text { Paperwork } \\
\text { Intake forms inclusive and culturally } \\
\text { appropriate }^{b}\end{array}$ & $\begin{array}{l}1,2,3,5,7,8,9 \\
10,11\end{array}$ & $\begin{array}{l}\text { Differing STI patterns and specific safer sex } \\
\text { methods }\end{array}$ & $2,3,4,5,9,10,11$ \\
\hline $\begin{array}{l}\text { Optional self-identification on forms } \\
\text { Policies and procedures }\end{array}$ & 1 & $\begin{array}{l}\text { Higher risks } \\
\text { Men: higher rate of anal cancer, risk for } \\
\text { heart disease }\end{array}$ & $3,4,5,9,10,11$ \\
\hline $\begin{array}{l}\text { Antidiscrimination, specifically include LGB } \\
\text { Have policy visible to clients }\end{array}$ & $\begin{array}{l}1,4,10 \\
1,3,4,5,7,9 \\
10,11\end{array}$ & $\begin{array}{l}\text { Women: risks for breast and ovarian cancer, } \\
\text { heart disease } \\
\text { Coming out issues }\end{array}$ & $2,3,4,5,7,9,10$ \\
\hline Complaints procedures available & 1,9 & Body image, weight, exercise, diet & $2,3,4,5,9$ \\
\hline $\begin{array}{l}\text { Involve LGB people: feedback, service } \\
\text { planning }\end{array}$ & $4,5,7,8,10$ & $\begin{array}{l}\text { Same-sex relationships including domestic } \\
\text { violence }\end{array}$ & $4,5,7,10$ \\
\hline $\begin{array}{l}\text { Clinician-patient communication } \\
\text { Attitudes }\end{array}$ & & $\begin{array}{l}\text { Legal recognition of relationship and } \\
\text { parenting }\end{array}$ & $4,5,9,10$ \\
\hline Overtly nonjudgmental & $2,3,4,7,9,10,11$ & Referral & \\
\hline Affirming & $7,9,11$ & LGB support groups, information network & $3,4,5,7,11$ \\
\hline Conceal negative attitudes & 2 & LGB-sensitive specialists and allied health & $1,2,4,10$ \\
\hline Challenge negative attitudes in colleagues & $6,10,11$ & LGB-specific health care professionals & $1,6,7$ \\
\hline $\begin{array}{l}\text { Confidentiality assured } \\
\text { Language }^{c}\end{array}$ & $\begin{array}{l}1,3,4,5,6,7,8 \\
\quad 9,10,11\end{array}$ & $\begin{array}{l}\text { Staff and training } \\
\text { Receptionists: confidentiality, use of intake } \\
\text { forms }\end{array}$ & $1,3,5$ \\
\hline $\begin{array}{l}\text { Gender-neutral, culturally aware, inclusive } \\
\text { Clarify and use patient's terms }\end{array}$ & $\begin{array}{l}2,3,4,6,8,9 \\
10,11 \\
2,3,6,7,9\end{array}$ & $\begin{array}{l}\text { All staff: antihomophobia, relevant LGB issues } \\
\text { Nondiscrimination policy including sexual } \\
\text { orientation }\end{array}$ & $\begin{array}{l}1,5,7,8,9,10,11 \\
1,8,9\end{array}$ \\
\hline Interviewing skills & & Support visibility of LGB employees & $1,5,9$ \\
\hline Open questions & $2,3,4,7,9,10,11$ & Affirmative action to hire LGB staff & 7 \\
\hline Inclusive of partner & $2,3,5,10$ & Population health & \\
\hline Inclusive of nonbiological parent & 5,11 & Marketing service to LGB community & $7,9,10$ \\
\hline Normalize sexual history: ask all patients & 9,11 & Health promotion targeted to LGB & $1,5,9$ \\
\hline $\begin{array}{l}\text { Avoid assumptions (eg, about congruence, } \\
\text { fluidity) }\end{array}$ & $2,3,4,5,7,8,9$ & $\begin{array}{l}\text { Community outreach: relationship with LGB } \\
\text { agencies }\end{array}$ & $1,5,8,10$ \\
\hline Disclosure & & Advocacy & $1,2,9$ \\
\hline Facilitation of disclosure, explain why asking & $2,6,8,11$ & & \\
\hline $\begin{array}{l}\text { Care with reactions to disclosure, respond } \\
\text { positively }\end{array}$ & $2,3,11$ & & \\
\hline Direct inquiry about sexual behavior/identity & $2,7,9,10,11$ & & \\
\hline Respect nondisclosure & $2,3,7$ & & \\
\hline
\end{tabular}

$\mathrm{LGB}=$ lesbian, gay, and bisexual; SES = socioeconomic status; STI = sexually transmitted infection.

a See Table 2 for details on each document.

b Sample intake forms: documents 2, 3, 7, 9 .

' Patient interview suggestions: documents $2,4,9,10,11$. 
researched and wrote the document, which was then reviewed by the leading body for general practice. ${ }^{37}$ Finally, the field of LGB health research is expanding rapidly, so it would be reasonable to include a recommended time line of about 5 years before the guideline is updated with new evidence.

\section{Implications for Clinical Practice and Future Research}

The synthesized recommendations from the appraised documents could be readily applied to existing primary care systems. Most of the recommendations would require minimal change and no cost to practice systems, which are prerequisites for uptake of guidelines by primary care clinicians. ${ }^{22}$ The areas of special knowledge for LGB health care contained in the recommendations would improve the LGB cultural competence of clinicians that LGB clients expect. For example, clinicians could make minor changes to their communication style and language that would help LGB people to feel more comfortable. The recommendations could also provide primary care services with ways to improve policies and procedures and local LGB population health initiatives. At the policy level, they could encourage the development of guidelines targeted to specific areas of the health system including primary care.

The gaps identified in the existing guidelines could be addressed within future research, in particular focusing on the primary care setting. For example, most of the guidelines reviewed made general statements pertaining to the LGB group as a whole, rather than highlighting specific health care needs according to sex, diverse expression of sexual orientation, socioeconomic status, age, and ethnicity. Further, research that examines the complexities of disclosure of sexual orientation would add much needed depth to future guidelines

Future LGB guidelines should be specifically and rigorously developed for primary care. Primary care organizations should be involved in this process to ensure that the guidelines satisfy their local needs and are disseminated widely. Finally, an evaluation and review process must be built into the implementation plan to understand whether the desired improvement in access, cultural competence, and quality health care has been achieved.

To read or post commentaries in response to this article, see it online at http://www.annfammed.org/cgi/content/full/8/6/533.

Key words: Homosexuality, male; homosexuality, female; bisexuality; female; male; minority groups; delivery of health care; standards; guidelines; evidence-based medicine; primary care

Submitted August 28, 2009; submitted, revised, June 11, 2010; accepted June 23, 2010.
Versions of this article have been presented at the Annual Meeting of Sexual Health Physicians, May 22, 2009, Queensland, Australia, and at the Wonca Asia Pacific conference/Royal Australian College of General Practitioners annual congress, October 3-5, 2008, Melbourne, Australia.

Funding support: The first author received a National Health and Medical Research Council (NHMRC, Australia) Primary Care Research PhD Scholarship, and a research grant from the Royal Australian College of General Practitioners, which supported the conduct of this systematic review.

\section{References}

1. Mayer KH, Bradford JB, Makadon HJ, Stall R, Goldhammer $H$, Landers S. Sexual and gender minority health: what we know and what needs to be done. Am J Public Health. 2008;98(6):989-995.

2. Peterkin A, Risdon C. Caring for Lesbian and Gay People: A Clinical Guide. Toronto, Canada: Toronto University Press; 2003.

3. McNair RP. Outing lesbian health in medical education. Women Health. 2003;37(4):89-103.

4. Solarz AL. Lesbian Health: Current Assessment and Directions for the Future. Washington, DC: Committee on Lesbian Health Research Priorities, Neuroscience and Behavioral Health Program, Health Sciences Policy Program, Health Sciences Section, Institute of Medicine; 1999.

5. Sell RL, Becker JB. Sexual orientation data collection and progress toward Healthy People 2010. Am J Public Health. 2001;91(6):876-882.

6. Peel E. Lesbian and gay awareness training: challenging homophobia, liberalism and managing stereotypes. In: Coyle A, Kitzinger C, eds. Lesbian and Gay Psychology: New Perspectives. Oxford, United Kingdom: Blackwell; 2002:255-274.

7. Hinchliff S, Gott M, Galena E. 'I daresay I might find it embarrassing': general practitioners' perspectives on discussing sexual health issues with lesbian and gay patients. Health Soc Care Community. 2005;13(4):345-353

8. Eliason MJ, Schope R. Does don't ask don't tell apply to health care? Lesbian, gay, and bisexual people's disclosure to health care providers. J Gay Lesbian Med Assoc. 2001;5(4):125-134

9. Dahan R, Feldman R, Hermoni D. Is patients' sexual orientation a blind spot of family physicians? J Homosex. 2008;55(3):524-532.

10. Mravcak SA. Primary care for lesbians and bisexual women. Am Fam Physician. 2006;74(2):279-286.

11. Clark ME, Landers S, Linde R, Sperber J. The GLBT Health Access Project: a state-funded effort to improve access to care. Am J Public Health. 2001;91(6):895-896

12. Schilder AJ, Kennedy C, Goldstone IL, Ogden RD, Hogg RS, O'Shaughnessy MV. "Being dealt with as a whole person." Care seeking and adherence: the benefits of culturally competent care. Soc Sci Med. 2001;52(11):1643-1659.

13. Hutchinson MK, Thompson AC, Cederbaum JA. Multisystem factors contributing to disparities in preventive health care among lesbian women. J Obstet Gynecol Neonatal Nurs. 2006;35(3):393-402.

14. Beagan BL, Kumas-Tan Z. Approaches to diversity in family medicine: "I have always tried to be colour blind." Can Fam Physician. 2009;55(8):e21-e28.

15. Grimshaw J, Eccles M, Tetroe J. Implementing clinical guidelines: current evidence and future implications. J Contin Educ Health Prof. 2004;24(Suppl 1):S31-S37.

16. Council on Scientific Affairs A. Health care needs of gay men and lesbians in the USA. JAMA. 1996;275(17):1354-1359.

17. Australian Medical Association. Position Statement on Sexual Identity and Gender Diversity. 2002. http://ama.com.au/node/552. Accessed October 27, 2010. 
18. Schneider JS, Levin S. Uneasy partners: the lesbian and gay health care community and the AMA. JAMA. 1999;282(13):1287-1288.

19. Adams J, Braun V, McCreanor T. Warning voices in a policy vacuum: professional accounts of gay men's health in Aotearoa New Zealand. Soc Pol J New Z. 2007;(30):199-215.

20. Davis D. Continuing education, guideline implementation, and the emerging transdisciplinary field of knowledge translation. J Contin Educ Health Prof. 2006;26(1):5-12.

21. Atkins D, Best D, Briss PA, et al; GRADE Working Group. Grading quality of evidence and strength of recommendations. BMJ. 2004;328(7454):1490.

22. Grol R, Dalhuijsen J, Thomas S, Veld C, Rutten G, Mokkink H. Attributes of clinical guidelines that influence use of guidelines in general practice: observational study. BMJ. 1998;317(7162):858-861.

23. Higgins J, Green S, eds. Cochrane Handbook for Systematic Reviews of Interventions. Issue 4. Chichester, United Kingdom: John Wiley \& Sons; 2006.

24. AGREE Collaboration. Development and validation of an international appraisal instrument for assessing the quality of clinical practice guidelines: the AGREE project. Qual Saf Health Care. 2003;12(1):18-23

25. Ollenschläger G, Marshall C, Qureshi S, et al; Board of Trustees 2002, Guidelines International Network (G-I-N). Improving the quality of health care: using international collaboration to inform guideline programmes by founding the Guidelines International Network (G-I-N). Qual Saf Health Care. 2004;13(6):455-460.

26. Royal College of Nursing and UNISON. Not 'Just' a Friend: Best Practice Guidance on Health Care for Lesbian, Gay and Bisexual Service Users and Their Families. London, UK: Royal College of Nursing and UNISON; 2004.

27. GLBT Health Access Project. Community Standards of Practice for Provision of Quality Health Care Services for Gay, Lesbian, Bisexual and Transgendered Clients. Boston, MA: Justice Resource Institute; 1997.

28. Public Health, Seattle and King County. Culturally Competent Care for GLBT People: Recommendations for Health Care Providers. Seattle WA: Public Health, Seattle and King County; 2010. http://www.king county.gov/healthservices/health/personal/glbt/CulturalCompetency .aspx. Accessed August 22, 2010.
29. NHS Inclusion Project and Stonewall Scotland. Fair For All-The Wider Challenge. Good LGBT Practice in the NHS. Glasgow, Scotland: NHS Scotland and Stonewall Scotland; 2005.

30. Hudspith M. Caring for Lesbian Health: A Resource for Canadian Health Care Providers, Policy Makers and Planners. British Columbia, Canada: Ministry of Health and Ministry Responsible for Seniors; 2001. Report 1-894356-16-0.

31. Kaiser Permanente. A Provider's Handbook on Culturally Competent Care: Lesbian, Gay, Bisexual and Transgendered Population. Oakland, CA: National Diversity Council, Kaiser Permanente; 2000.

32. Makadon HJ, Mayer K, Potter J, Goldhammer H, eds. Fenway Guide to Lesbian, Gay, Bisexual and Transgender Health. Philadelphia, PA: American College of Physicians; 2007.

33. Leonard W, ed. What's the Difference? Health Issues of Major Concern to Gay, Lesbian, Bisexual, Transgender and Intersex (GLBTI) Victorians. Melbourne, Australia: Department of Human Services; 2002.

34. Leonard W, on behalf of the Ministerial Advisory Committee on Gay and Lesbian Health. Health and Sexual Diversity. A Health and Wellbeing Action Plan for Gay, Lesbian, Bisexual, Transgender and Intersex (GLBTI) Victorians. Melbourne, Australia: Victoria Government Department of Human Services; 2003.

35. Gay and Lesbian Health Victoria. Sexual Diversity Health Services Audit. Melbourne, Australia: Australian Research Centre in Sex Health and Society, La Trobe University; 2004.

36. Gay and Lesbian Medical Association. Guidelines for Care of Lesbian, Gay, Bisexual and Transgender Patients. San Francisco, CA: Gay and Lesbian Medical Association; 2006.

37. Allen O. Lesbian, Gay \& Bisexual Patients: The Issues for General Practice. Dublin, Ireland: Irish College of General Practitioners and the Gay and Lesbian Equality Network; 2008.

38. Martin JI, Knox J. Methodological and ethical issues in research on lesbians and gay men. Soc Work Res. 2000;24(1):51-59.

39. Arnold LM. Promoting culturally competent care for the lesbian gay, bisexual, and transgender population. Am J Public Health. 2001;91(11):1731. 